\title{
Sallie Chisholm (1947): Recipient of the 2013 Ramon Margalef Prize in Ecology
}

\author{
MONTSERRAT VIDAL \\ Department of Ecology, University of Barcelona, Avda. Diagonal 643, 08028 Barcelona, Catalonia, Spain. \\ E-mail:montsevidal@ub.edu
}

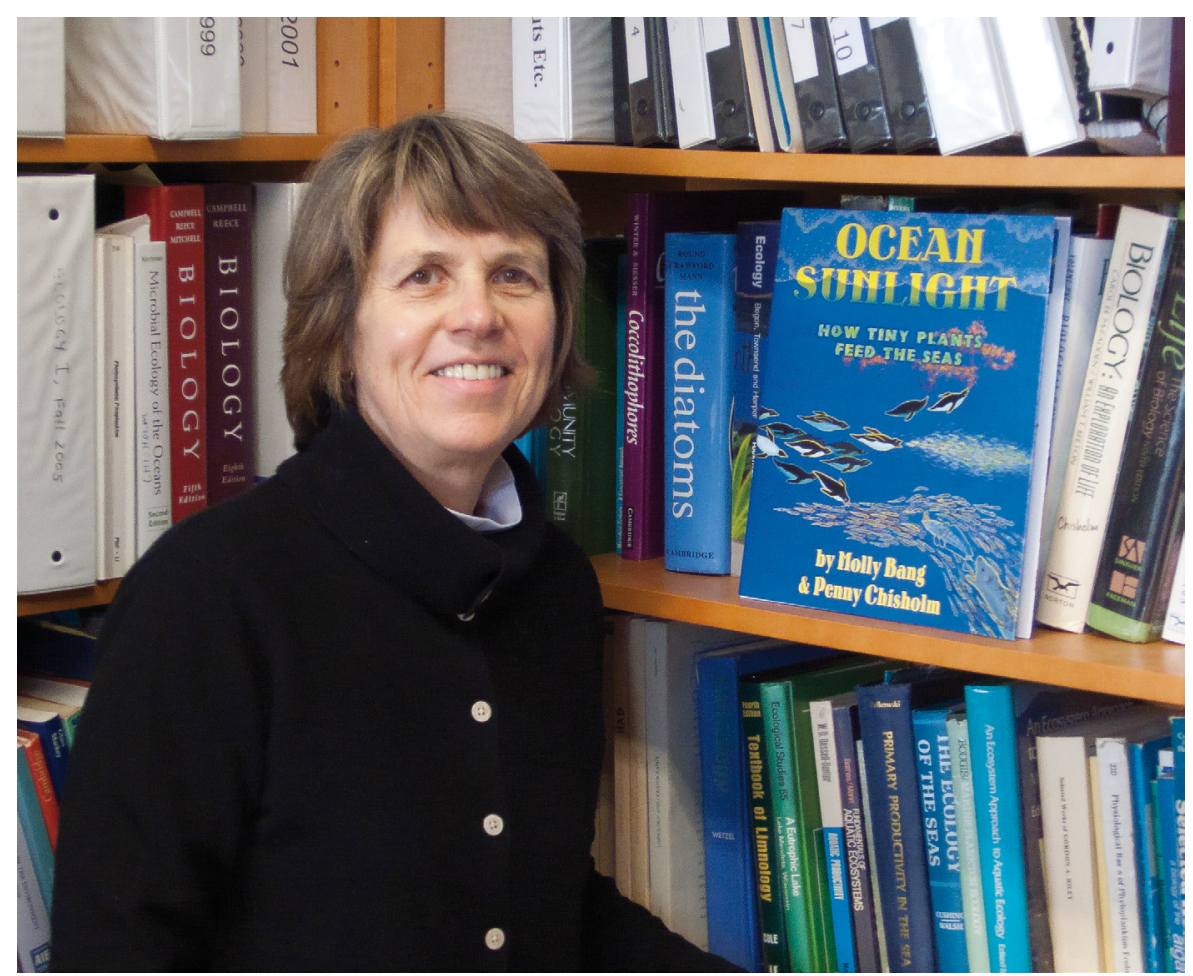

The Ramon Margalef Prize in Ecology is awarded annually by the Government of Catalonia to recognize people who have distinguished themselves in the field of ecological science. Among the events that are held in connection with the award-giving ceremony, the University of Barcelona hosts a seminar by the awardee followed by a roundtable discussion. I had the honour of chairing this event on October 23, 2013. Some colleagues commented that my presentation of
Dr. Chisholm and the science she conducts could be of interest to the readership of Scientia Marina, so here it is with minor adaptations to make it suitable for publication.

Dr. Chisholm is currently a professor in the Biology Department at the Massachusetts Institute of Technology. Although her scientific career started in the world of algal ecophysiology, she attained international recognition in 1988 for the discovery of Prochlorococcus, 
the small bacterium that has proven to be the most abundant photosynthetic organism on the planet.

The discovery of Prochlorococcus made it possible to identify the trophic base of the large ocean deserts and changed our approach to the ocean's diversification mechanisms. Soon after several ecotypes were identified, which were mainly adapted to different conditions of light and temperature. But that was only the beginning. To give you an idea of the great diversity of this group, each Prochlorococcus cell contains about 2000 genes and some 57000 genes have been recorded in what Dr. Chisholm calls the "global Prochlorococcus federation gene pool", about four times more than the number found in humans.

Part of the fascination of Phrochlorococcus is due to the way it adapts in order to survive in the impoverished environment of the central regions of the oceans. Both Phrochlorococcus and Synechococcus have extremely low phosphorus requirements. Dr. Chisholm and her collaborators have interpreted this as a strategy against lytic viral infections, which require a great deal of phosphorus, in favor of lysogenic ones, which can be more stable. This strategy is associated with low growth and seems to be quite common in open-ocean species.

There also is a great variability in the possession of specific genes involved in the acquisition and use of nutrients. Interestingly, variability in the content and architecture of these genes is unrelated to phylogeny and quite closely related to the nutrient characteristics of the environment. Cells of Phrochlorococcus from phosphorus-deficient regions contain more genes involved in phosphorus acquisition than those from phosphorus-rich regions. It is thought that these genes may have been acquired through lateral gene transfer mechanisms. All of this gives enormous possibilities for adapting to different environmental conditions. Dr. Chisholm's research in this field has led to a radical change in the way we study and understand the strategies of these organisms, how life has been built throughout evolution, and how the incorporation of genes from different sources has enabled these cells to adapt to the austerity of the ocean's oligotrophic habitats.

We also thank Dr. Chisholm for considering the ocean from a different perspective when she became fascinated by Phrochlorococcus. Dr. Chisholm has excelled in the research of the high nutrient and low chlorophyll regions, in which the growth of phytoplankton does not deplete the available nutrients. Three of these regions have been recognized: the sub-Arctic Pacific, the Equatorial Pacific and the Southern Ocean around Antarctica. These regions with excess nutrients are important because they occupy $25 \%$ of the ocean's surface. It was immediately realized that if all these nutrients could be used for primary production they would have a very great impact on the concentration of carbon dioxide in the atmosphere, but something prevents phytoplankton from exhausting these nutrients.
Possible causes that have been suggested include the type of trophic structure, which could prevent massive growth of phytoplankton in the sub-Arctic Pacific, light limitation in the Southern Ocean, and iron limitation. Meanwhile, a great deal of oceanographic research has been carried out. In 1991, in collaboration with François Morel, Dr. Chisholm edited a special volume of the journal Limnology \& Oceanography under the title "What regulates phytoplankton production in the nutrient-rich areas of the open sea?", which analyzed the importance of different factors in each of the three regions. It is still a benchmark text today. However, from the start iron was thought to be the main limiting factor that prevents the depletion of nutrients in these regions. Accordingly, it was considered that simply by adding iron and waiting for the growth of plankton to transfer organic carbon to the deep water, we would have a mechanism for mitigating the excess carbon dioxide in the atmosphere. Furthermore, by fertilizing $50 \%$ of the most oligotrophic ocean surface we could achieve a similar result.

Suffice it to say that despite evidence of iron limitation in some of these nutrient-rich regions, the response of carbon fluxes to iron enrichment has been varied and their effectiveness for transferring carbon dioxide into the ocean has not been demonstrated. In the words of Dr. Chisholm, the history of iron reveals why straightforward answers to simple questions are difficult to come by in biological oceanography.

The success of proposals for ocean fertilization has a lot to do with the human condition, which is so deeply rooted in agriculture. Why not add what is needed and cultivate the ocean? What's wrong with facilitating a natural process? Maybe it also has to do with the simplicity of the message: if the problem of these regions is the lack of iron, for example, we can apply the same solution everywhere. The diversity of the real world is not well received, and goes against the business interests of selling iron for carbon dioxide credits.

But reality is stubborn and nature insists on maintaining its natural trophic structure, recycling a lot, separating a little, and slowing things down. This is the parsimony of nature discussed so much by Ramon Margalef. Separating the ingredients of the productive mix: the light from nutrients, iron from nitrogen and phosphorus. But what's wrong with an excess of nutrients? In fact, what is left over in one place is used elsewhere. We know that the nutrients that are not consumed in the Southern Ocean end up feeding blooms, production and fisheries in distant regions. The ocean is inter-connected and horizontal transport is the most typical feature of ocean ecosystems, as was also stated by Margalef.

Dr. Chisholm shows us very clearly that with regard to Phrochlorococcus and after two decades of research in regions with excess nutrients the only attitude one can take is one of humility and prudence. We must admit that we do not know everything and warn of the danger of thinking that we do. Not all the ocean 
is the same. It is true that we have no way to appreciate the differences, to see the valleys, the ocean deserts and the seamounts, but we now have sensors and we have eyes in space. There remains the task of training professionals and transmitting this knowledge to society, which has to be encouraged from the universities. However, our cross-disciplinary field of study is still misunderstood, and governments are reluctant to support costly teaching and research whose utility is often not perceived.

Dr. Chisholm participated in the first study carried out in the equatorial Pacific and already in 1995 she warned of the dangers to ecosystems posed by massive iron fertilization and the conflicts that arise in the border between research, politics and business. She maintained this position in later publications, such as "Discrediting Ocean fertilization" in 2001, "Ocean fertilization: time to move on" in 2009 , and other works focusing more on summarizing results. We have to thank Dr. Chisholm for taking such a determined involvement in the dissemination of scientific results at a difficult time of political and economic pressure arising from the sale of carbon dioxide emission credits. Despite attempts at regulation by the United Nations and other international organizations, the issue is not closed, as is demonstrated by very recent fertilization initiatives.

Dr. Chisholm has made an important contribution to recent oceanography and provides a model as a brilliant and committed researcher. I therefore feel honoured to present her and reiterate my appreciation for her presence in this building named after Ramon Margalef, who gave so many of us a passion for ecology and oceanography.

Thank you Dr. Chisholm for your wonderful work on Phrochlorococcus and the tiny life forms in the oceans and for sharing with us such interesting views on how life evolves and diversifies in the impoverished ocean habitats. Thank you also for your personal commitment to caring for our planet and for warning of the risk of large-scale human perturbations. Thank you for your rigorous thinking. And finally, thank you for joining us in this session and for the opportunity to discuss with you the many questions that your research has raised.

\section{BIBLIOGRAPHY}

Bertilsson S., Berglund O., Karl D.M., Chisholm S.W. 2003. Elemental composition of marine Prochlorococcus and Synechococcus: Implications for the ecological stoichiometry of the sea. Limnol. Oceanogr. 48: 1721-1731

Chisholm S.W. 1995. The Iron Hypothesis: Basic research meets environmental policy. In Weller R. (ed.), Reviews of Geophysics, Supplement, US National Report to International Union of Geodesy and Geophysics 1991-1994, July 1995, 1277-1286.

Chisholm S.W. 2000. Stirring Times in the Southern Ocean. Nature (News and Views) 407: 685-687.

Chisholm S.W. 2012. Unveiling Prochlorococcus: The Life and times of the ocean's smallest photosynthetic cell. In: Kolter R. Maloy S. (eds), Microbes and evolution: The world that Darwin never saw. ASM Press. p. 165. [Also published in 2011 in Microbe 6(6): 280-283 (cover story)].

Chisholm S.W., Morel F.M.M. (eds). 1991. What regulates phytoplankton production in nutrient-rich areas of the open sea? Limnol. Oceanogr. Special Ed., 36(8).

Chisholm S.W., Olson R.J., Zettler E.R., Goericke R., Waterbury J., Welschmeyer N. 1988. A novel free-living prochlorophyte abundant in the oceanic euphotic zone. Nature 334(6180): 340-343.

Chisholm S.W., Frankel S.L., Goericke R., Olson R.J.,Palenik B., Waterbury J.B., West-Johnsrud L., Zettler E.R. 1992. Prochlorococcus marinus nov. gen. nov. sp.: an oxyphototrophic marine prokaryote containing divinyl chlorophyll a and b. Arch. Microbiol. 157: 297-300.

Chisholm S.W., Falkowski P.G., Cullen J.J. 2001. Dis-crediting ocean fertilization. Science 294: 309-310.

Follows M., Dutkiewicz S., Grant S., Chisholm S.W. 2007. Emergent biogeography of microbial communities in a model ocean. Science 315: 1843-1846

Lindell D., Jaffe J.D., Coleman M.1., Axmann I.M., Rector T., Kettler G., Sullivan M.B., Steen R., Hess W.R., Church G.M., Chisholm S.W. 2007. Genome-wide expression dynamics of a marine virus and host reveal features of coevolution. Nature 449: 83-86

Margalef R. 1991. Teoría de los ecosistemas ecológicos. Publicacions Universitat de Barcelona.

Margalef, R. 1997. Our Biosphere, Ecology Institute, Oldendorf/ Luhe.

Martin J.A. and the IRONEX Group. 1994. Testing the iron hypothesis in ecosystems of the equatorial Pacific Ocean. Nature 371: 123-148.

Martiny A.C., Tai A.P.K., Veneziano D., Primeau F., Chisholm S.W. 2009. Taxonomic resolution, ecotypes, and the biogeography of Prochlorococcus. Env. Microbiol. 11: 823-832.

Strong A., Chisholm S., Miller C., Cullen J. 2009. Ocean fertilization: Time to move on. Nature 361: 347-348.

Strong A.L., Cullen J.J., Chisholm S.W. 2009. Ocean fertilization: Science, policy and commerce. Oceanography 22(3): 236-261.

Scient. ed.: F. Peters.

Received October 25, 2013. Accepted November 4, 2013.

Published online November 27, 2013. 